\title{
Desain Pengembangan Aktivitas Kemahasiswaan dengan Pendekatan Psychological Capital dalam Meningkatkan Minat dan Kemampuan Berwirausaha Mahasiswa Fakultas Ekonomi UNTAN
}

\author{
M. Irfani Hendri* \\ Universitas Tanjungpura \\ Indarti Rochayati \\ Universitas Tanjungpura \\ M. Fahmi \\ Universitas Tanjungpura
}

\begin{abstract}
This paper is to describe what has been done by the Faculty of Economics UNTAN in growing interest and entrepreneurship skills among students through student activities and current evaluation tried to offer a development design of student activities with the approach of psychological capital that includes (1) the existence of self-confidence (self confidence); (2) positive attribution (optimism); (3) resistance in achieving its objectives with the ability to redefine the path to reach the goal with the ability to redefine the path to peak at the destination if required (hope); and (4) when facing problems and difficulties, able to survive and continue forward (resiliency) to achieve success. The approach taken in this study is qualitative, type of research is a case study. For purposes of analysis, data can be collected using triangulation of data collection methods which involves observation, interview documentation and Focus Group Discussion (FGD). It can be concluded that the hardest thing in the printing of an entrepreneur is the mental change that is formed because of the mindset that the synergy of a wide range of our daily interactions (family, education, environment, etc.). It is an attempt to solve the mental problem needs to be a synergy of various growth entrepreneurship program that has a good and concrete step in creating the entrepreneurs.
\end{abstract}

Keywords : student activities, psychological capital, entrepreneurship

\section{PENDAhULUAN}

Tumbuh dan berkembangnya para wirausahawan dalam jumlah yang memadai merupakan prasyarat bagi kemajuan suatu bangsa. Menurut banyak ahli entrepreneurship, paling tidak dibutuhkan $2 \%$ wirausahawan dari total populasi sebuah

\footnotetext{
* Korespondensi: M. Irfani Hendri, Jurusan Manajemen, Fakultas Ekonomi, Universitas Tanjungpura, Jalan Prof. Dr. H. Hadari Nawawi, Pontianak, Indonesia. Email: irfani2011@ yahoo.co.id
} 
negara supaya negara tersebut bisa menggapai kemajuan (Hendri, 2012). Jumlah persentase wirausaha di Indonesia berdasarkan data dari Kementerian Koperasi dan Usaha Kecil Menengah (Kemenkop dan UKM) sampai dengan Tahun 2013 baru sebesar 1,65 persen dari jumlah penduduk di Indonesia. Angka ini masih sangat rendah jika dibandingkan dengan negara tetangga yaitu Malaysia dan Singapura, dimana Malaysia sudah mencapai angka 3 persen sedangkan Singapura jauh lebih tinggi lagi yaitu 7 persen dari jumlah penduduknya.

Ada banyak faktor yang menyebabkan jumlah wirausahawan kita masih sedikit, salah satu diantaranya adalah orientasi sebagian besar lulusan Perguruan Tinggi lebih sebagai pencari kerja (job seeker) dibandingkan sebagai pencipta lapangan pekerjaan (job creator). Kondisi demikian bisa jadi disebabkan karena sistem pembelajaran yang diterapkan di berbagai perguruan tinggi saat ini lebih terfokus pada bagaimana menyiapkan para mahasiswa yang cepat lulus dan mendapatkan pekerjaan, bukannya lulusan yang siap menciptakan pekerjaan (Pedoman PMW Dikti, 2009).

Menjadi Pegawai Negeri Sipil (PNS) juga masih merupakan primadona dan pilihan utama para lulusan tersebut dalam memilih pekerjaan, walaupun untuk sekedar mengikuti tes PNS tersebut mereka rela menunggu waktu yang cukup lama dan ini tentunya berdampak pada lamanya lulusan tersebut dalam penyerapan di pasar kerja (Hendri, 2012).

Menurut Hendri (2012) sebenarnya telah banyak upaya yang dilakukan oleh Direktorat Jenderal Pendidikan Tinggi (Ditjen Dikti) dalam mengembangkan kewirausahaan di kalangan mahasiswa. Melalui aktivitas akademik, sudah banyak kampus yang menawarkan mata kuliah Kewirausahaan kepada para mahasiswanya. Dengan mata kuliah Kewirausahaan ini diharapkan dapat membentuk karakter wirausaha di kalangan mahasiswa atau minimal para mahasiswa menambah pengetahuan dan wawasannya dalam memahami seluk-beluk bisnis baik dari sisi soft skill maupun hard skill. Dengan demikian para mahasiswa diharapkan memiliki kemampuan dalam memanfaatkan segala peluang yang ada di sekitarnya dalam menciptakan usaha sendiri setelah lulus maupun pada saat masih kuliah.

Selain melalui mata kuliah kewirausahaan, untuk menumbuhkan kewirausahaan di kalangan mahasiswa, maka sejak Tahun 2002 Direktorat Jenderal Pendidikan Tinggi juga telah memperkenalkan Program Kreativitas Mahasiswa (PKM) yang merupakan salah satu program penalaran dalam bentuk kegiatan pendidikan, penelitian dan pengabdian kepada masyarakat yang dilaksanakan oleh mahasiswa secara berkelompok (3 - 5 orang) dan dosen sebagai pembimbing. Bahkan, pada Tahun 2009 Ditjen Dikti juga telah meluncurkan Program Mahasiswa Wirausaha (Entrepreneur Student Program) atau lebih dikenal dengan singkatan PMW. PMW ini diharapkan mampu mendukung visi - misi pemerintah dalam mewujudkan kemandirian bangsa melalui penciptaan lapangan kerja dan pemberdayaan Usaha Kecil Menengah (Pedoman PMW Dikti, 2009). Selain itu, Bank Mandiri sejak Tahun 2007 juga telah meluncurkan 
Program Wirausaha Mandiri dengan berbagai macam kegiatan diantaranya Penghargaan Wirausaha Mandiri (PWM) bagi mahasiswa dan alumni (sarjana dan pascasarjana). Selain Ditjen Dikti dan Bank Mandiri, Kemenkop dan UKM R.I dan Kemenpora R.I juga memiliki berbagai program yang mencoba untuk mengubah orientasi kalangan intelektual muda tersebut dari job seeker menjadi job creator.

Berbagai program kewirausahaan tersebut ternyata memberikan dampak terhadap minat berwirausaha di kalangan mahasiswa yang semakin meningkat. Berdasarkan data dari Bank Mandiri dari waktu ke waktu jumlah peserta yang mengikuti PWM kian meningkat. Jika pada Tahun 2007 jumlah peserta baru 488 orang dari 26 Perguruan Tinggi (PT), Tahun 2008 meningkat menjadi 1.057 orang dari 198 PT, Tahun 2009 bertambah menjadi 1.706 orang dari 200 PT dan Tahun 2010 meningkat lagi menjadi 3.294 orang dari 412 PT. Bahkan PWM telah menjadi kegiatan unggulan program Corporate Social Responsibility (CSR) Bank Mandiri (Majalah Bank Mandiri, 2011). Begitupun yang terjadi pada mahasiswa UNTAN dalam mengikuti PMW, dimana minat mahasiswa UNTAN dalam mengikuti PMW mengalami peningkatan, walaupun setiap tahun sistem penyeleksiannya semakin ketat dan sistem pendanaan juga mengalami perubahan dari yang bersifat hibah berubah menjadi pinjaman tanpa bunga.

Pengaruh antara PMW UNTAN terhadap minat berwirausaha ini juga pernah diteliti dalam penelitian skripsi Sastri (2010) yang melakukan penelitian terhadap peserta PMW FKIP UNTAN Tahun 2009. Dimana dari hasil penelitian Sastri (2010) dapat disimpulkan bahwa PMW UNTAN Tahun 2009 berpengaruh terhadap minat berwirausaha mahasiswa FKIP UNTAN dan koefisien determinasi menunjukkan angka $47 \%$ yang berarti kontribusi PMW UNTAN terhadap minat berwirausaha mahasiswa FKIP UNTAN adalah sebesar $47 \%$. Pada Grafik 1, bisa dilihat jumlah proposal mahasiswa UNTAN yang didanai dari PMW UNTAN dari Tahun 2009 sampai dengan Tahun 2014.

Pada Grafik 1 dapat dilihat jumlah proposal usaha yang telah didanai dalam PMW UNTAN dari Tahun 2009 s.d. 2014. Tahun 2009 ada 39 proposal usaha yang telah didanai, Tahun 2010 meningkat menjadi 81 proposal, Tahun 2011 ada 75 proposal usaha yang didanai, Tahun 2012 ada 45 proposal, Tahun 2013 meningkat lagi menjadi 62 proposal serta Tahun 2014 ada 48 proposal usaha yang telah didanai. Sehingga, dari sejak Tahun 2009 s.d. 2014 UNTAN telah mencetak 350 wirausaha baru yang berasal dari PMW UNTAN.

Selain melalui PMW, UNTAN juga merupakan salah satu perguruan tinggi yang aktif dalam mendorong para mahasiswanya untuk mengembangkan kewirausahannya melalui Program Kreativitas Mahasiswa (PKM). Ada beberapa jenis PKM yaitu PKM Kewirausahaan (PKM-K), PKM- Penelitian (PKM-P), PKM- Pengabdian Pada Masyarakat (PKM-M), PKM - Gagasan Tertulis (PKM-GT) dan PKM- Karya Cipta (PKM-KC). 


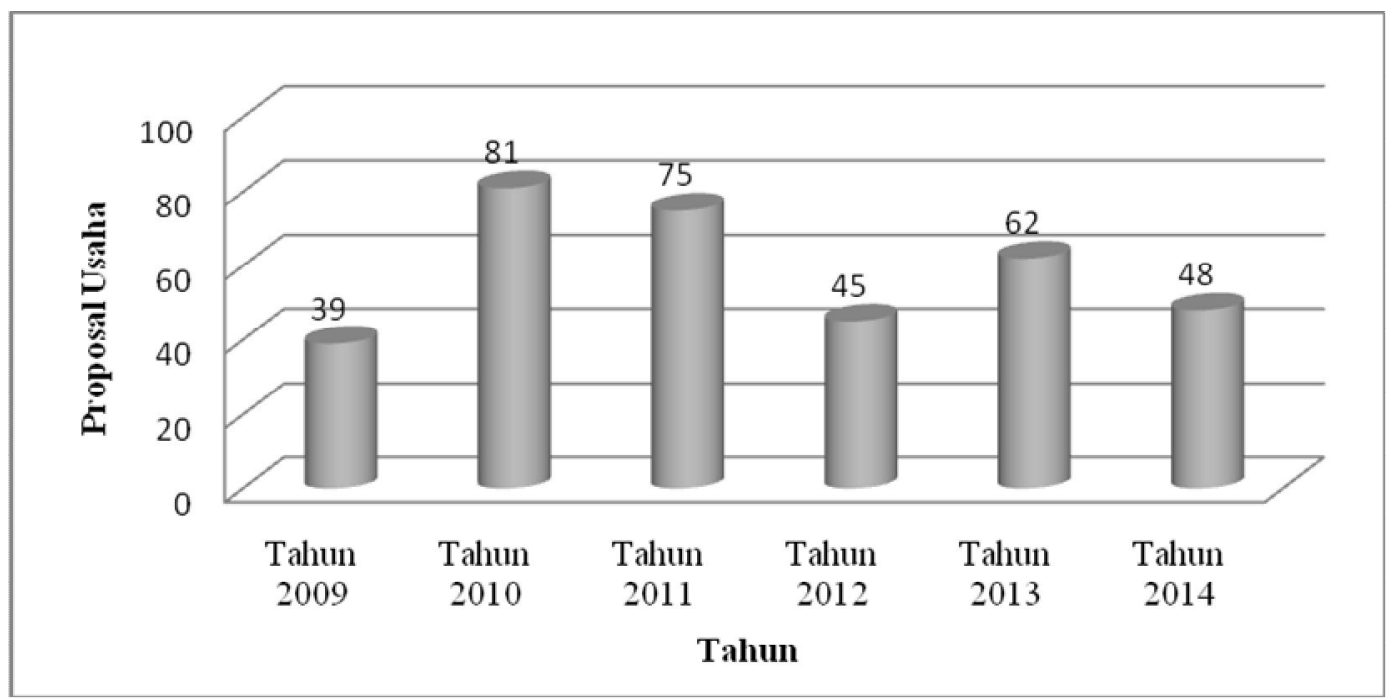

Grafik 1. Jumlah Proposal Usaha Yang Didanai Dalam PMW Untan 2009 - 2014

Keaktifan mahasiswa UNTAN dalam mengusulkan proposal PKM serta proposal yang telah didanai oleh Dikti dari sejak Tahun 2008 - 2010 berdasarkan jenis-jenis PKM dapat dilihat pada Lampiran 1.

Pada Lampiran 1 dapat dilihat selain jumlah proposal yang diusulkan dan didanai oleh Dikti setiap tahun mengalami peningkatan, juga dapat dilihat bahwa penyebaran jenis PKM terlihat bervariasi antara satu fakultas dengan fakultas yang lain. Misalnya, Fakultas Ekonomi lebih dominan dalam pengusulan PKM- Kewirausahaan, FMIPA lebih dominan dalam pengusulan PKM-Penelitian, F. Pertanian lebih dominan dalam PKMPengabdian Pada Masyarakat.

Antusiasme mahasiswa UNTAN dalam mengikuti program kewirausahaan baik melalui PMW maupun PKM memang menunjukkan angka yang semakin meningkat. Akan tetapi, dari hasil evaluasi terhadap peserta PMW UNTAN dari Tahun 2009 s.d. Tahun 2013 yang dilakukan oleh Bagian Kemahasiswaan UNTAN ada beberapa hal yang menjadi catatan dalam pelaksanaan PMW tersebut. Diantaranyasebagian besar mahasiswa penerima dana dalam PMW ini ternyata kurang memiliki kesungguhan untuk merealisasikan rencana bisnisnya, bahkan ada diantaranya pada saat menerima dana, bukannya dipergunakan untuk usaha tetapi hanya dibagi-bagikan kepada sesama mahasiswa dalam kelompok usaha tersebut. Selain itu, terkadang mahasiswa penerima dana PMW juga kurang jujur dalam melaporkan kondisi usaha dan dalam pemanfaatan dana yang telah mereka terima. Selain itu, ada juga diantara para calon wirausaha baru ini yang terkesan tidak memiliki kesabaran dalam menjalankan usahanya, sehingga pada saat mengalami kendala, mereka memutuskan untuk berhenti di tengah jalan.

Hal inilah kemudian yang menjadi pemikiran bahwa faktor utama dalam meningkatkan minat dan kemampuan berwirausaha di kalangan mahasiswa adalah bukan 
faktor modal semata melainkan faktor psychological capital. Psychological capital merupakan pendekatan untuk mengoptimalkan potensi psikologis yang dimiliki oleh individu. Psychological capital juga sangat berperan penting dalam menunjang niat dan minat yang kuat dalam berwirausaha (entrepreneurial intention), dimana entrepreneurial intention menurut Katz dan Gartner (dalam Indarti \& Rostiani, 2008) yaitu proses pencarian informasi yang dapat digunakan untuk mencapai tujuan pembentukan suatu usaha. Seseorang dengan intensi untuk memulai usaha akan memiliki keyakinan diri (efikasi diri), kesiapan dan kemajuan yang lebih baik dalam usaha yang dijalankan dibandingkan seseorang tanpa intensi untuk memulai usaha.

Tulisan ini untuk menggambarkan apa yang telah dilakukan oleh Fakultas Ekonomi UNTAN dalam menumbuhkan minat dan kemampuan berwirausaha di kalangan mahasiswanya melalui aktivitas kemahasiswaan dan dengan evaluasi yang ada mencoba menawarkan sebuah desain pengembangan aktivitas kemahasiswaan dengan pendekatan psychological capital dalam rangka meningkatkan minat dan kemampuan berwirausaha di kalangan di kalangan mahasiswa Fakultas Ekonomi UNTAN yang lebih baik lagi. Pemilihan obyek di tingkat Fakultas Ekonomibukan di tingkat UNTAN dengan pertimbangan bahwa setiap fakultas yang ada di UNTAN memiliki kondisi dan karakteristik yang berbeda. Selain itu, mahasiswa Fakultas Ekonomi UNTAN merupakan salah satu fakultas di UNTAN yang aktif dalam mengusulkan proposal usaha baik dalam program mahasiswa wirausaha (PMW) maupun dalam program Kreativitas mahasiswa kewirausahaan (PKM-K).

\section{TINJAUAN PUSTAKA}

\subsection{Psychological Capital}

Psycological capital adalah suatu pendekatan yang dicirikan pada dimensidimensi yang bisa mengoptimalkan potensi yang dimiliki individu sehingga bisa membantu kinerja organisasi (Osigweh, 1989). Psychological capital merupakan pendekatan untuk mengoptimalkan potensi psikologis yang dimiliki oleh individu yang dicirikan oleh : (1) adanya kepercayaan diri (self confidence) melakukan tindakan yang perlu untuk mencapai sukses dalam tugas-tugas yang menantang; (2) atribusi yang positif (optimism); (3) resistensi dalam mencapai tujuan dengan kemampuan mendefinisikan kembali jalur untuk mencapai tujuan, dengan kemampuan mendifinisikan kembali jalur untuk mencapi tujuan jika diperlukan (hope); dan (4) ketika menghadapi masalah dan kesulitan, mampu bertahan dan terus maju (resiliency) untuk mencapai kesuksesan (Luthan, youssef \& Avolio, 2007).

\subsection{Self-efficacy}

Self-efficacy atau kepercayaan diri didefinisikan oleh Bandura (dalam Stajkovic dan Luthan, 2001) sebagai keyakinan atau rasa percaya diri seseorang tentang 
kemampuannya untuk mengerahkan motivasinya, kemampuan kognitifnya serta tindakan yang diperlukan untuk melakukan dengan sukses dengan tugas tertentu dalam konteks tertentu.

\subsection{Hope}

Hope didefinisikan sebagai keadaan psikologis positif yang didasarkan pada kesadaran yang saling mempengaruhi antara agency (energi untuk mencapai tujuan) dan path ways, yakni perencanaan untuk mencapai tujuan (Snyder, Irving \& Anderson, 1991). Pada komponen ini, seseorang mampu menciptakan jalur-jalur alternatif untuk mencapai tujuan yang mereka inginkan ketika jalur asalnya tertutup atau mendapat halangan (Snyder,1994). Hal - hal yang dapat digunakan dalam mengembangkan hope : 1) Goal setting, menetapkan dan memperjelas dengan detail apa yang menjadi tujuan selama ini, 2) Stepping, memberikan penjelasan tentang langkah-langkah kongkrit dalam mencapai tujuan tersebut, 3) Participative initiatives, membuat beberapa alternatif apabila satu alternatif sulit dilalui, maka menggunakan alternatif yang selanjutnya untuk tetap mencapai tujuan, 4) Showing confidence, memberikan pengakuan pada diri individu bahwa proses yang dikerjakan untuk mencapai tujuan adalah hal yang disenangi dan tidak semata-mata fokus pada pencapaian aktir, 5) Preparedness, selalu siap menghadapi rintangan.

\subsection{Optimism}

Optimism adalah suatu explanatory style yang memberikan atribusi peristiwaperistiwa positif pada sebab-sebab yang personal, permanent serta pervasive dan menginterpretasikan peristiwa-peristiwa negatif pada faktor-faktor yang eksternal, sementara serta situasional. Sebaliknya, eksplanatory style yang pesimistis akan menginterpretasikan peristiwa positif dengan atribusi-atribusi yang eksternal, sementara serta situasional dan mengatribusi peristiwa negatif pada penyebab yang personal, permanent dan pervasive (Seligman,1998).

Schulman (1999) memberikan penjelasan untuk mengembangkan optimism : 1) Leniency for the pas, yaitu mengikhlaskan kegagalan yang telah dilakukan dan menata kembali apa yang akan dilakukan, 2) Appreciation for the present, yaitu memberikan apresiasi apa yang sedang dilakukan individu, baik itu mengenai kemampuannya maupun kelemahannya, bukan mencela diri sendiri, 3) Opportunity-seeking for the future, yaitu mendapatkan kesempatan kembali dimasa yang akan datang.

\subsection{Resiliency}

Resiliency didefinisikan Masten dan Reed (2002) sebagai kumpulan fenomena yang dikarakteristikkan oleh pola adaptasi positif pada kontek keterpurukan. Dalam pendekatan psychological capital definisi ini diperluas, tidak hanya kemampuan untuk kembali dari situasi keterpurukan namun juga kegiatan-kegiatan yang positif dan 
menantang, misalnya target penjualan dan kemauan untuk berusaha melebihi normal atau melebihi keseimbangan. Woling dan wolin (1994) mengemukakan tujuh aspek utama yang dimiliki oleh individu agar mencapai resilience yaitu: 1) insight, yaitu proses perkembangan individu dalam merasa, mengetahui dan mengerti masa lalunya untuk mempelajari perilaku-perilaku yang lebih tepat, 2) independence, yaitu kemampuan untuk mengambil jarak secara emosional maupun fisik dari sumber masalah, 3) relationships, individu yang resilience mampu mengembangkan hubungan yang jujur, saling mendukung dan berkualitas bagi kehidupan dan memiliki role model yang baik, 4) initiative, yaitu keinginan yang kuat untuk bertanggung jawab terhadap hidupnya, 5) creative, yaitu kemampuan memikirkan berbagai pilihan, konsekuensi dan alternatif dalam menghadapi tantangan hidup, 6) orality adalah kemampuan individu untuk berperilaku atas dasar hati nuraninya. Individu dapat memberikan kontribusinya dan membantu orang yang membutuhkannya.

\subsection{Minat dan Kemampuan Berwirausaha}

Minat dan kemampuan kewirausahaan adalah faktor penting dalam mengembangkan keberhasilan kewirausahaan terutama pada saat periode awal memanfaatkan sumber daya - sumber daya kewirausahaan. Seorang wirausahawan hendaknya seorang yang mampu menatap masa dengan lebih optimis. Melihat ke depan dengan berfikir dan berusaha. Usaha memanfaatkan peluang dengan penuh perhitungan. Orang yang berorientasi ke masa depan adalah orang yang memiliki persepktif dan pandangan kemasa depan. Karena memiliki pandangan jauh ke masa depan maka ia akan selalu berusaha untuk berkarsa dan berkarya (Suryana, 2004).

\section{METODE PENELITIAN}

Pendekatan yang dilakukan dalam penelitian ini adalah pendekatan kualitatif. Sedangkan jenis penelitian ini adalah studi kasus (case study). Untuk keperluan analisis, data dapat dikumpulkan dengan menggunakan metode pengumpulan data triangulasi (triangulation) yang melibatkan observasi, interview dan dokumentasi (Yin, 2006). Pengumpulan data dan informasi yang diperlukan untuk keperluan analisis dilakukan dengan 1) studi dokumentasi; 2) observasi lapangan; 3) wawancara dan 4) Focus Group Discussion (FGD).

\section{HASIL DAN ANALISIS}

\subsection{Deskripsi Program Pengembangan Kewirausahaan Yang Telah Dilakukan di FE UNTAN}

Fakultas Ekonomi UNTAN yang berdiri sejak Tahun 1959 memiliki tujuan utama yaitu menghasilkan ekonom yang berjiwa wirausaha, profesional dan memiliki etos kerja yang tinggi. Untuk mencapai tujuan tersebut, maka bidang kemahasiswaan dan 
alumni Fakultas Ekonomi UNTAN sejak Tahun 2007 sudah secara serius telah merancang berbagai aktivitas kemahasiswaan yang diarahkan untuk meningkatkan minat berwirausaha di kalangan mahasiswa Fakultas Ekonomi UNTAN.

Tahap awal pengembangan program kewirausahaan di Fakultas Ekonomi UNTAN adalah dengan mendirikan Inkubator Wirausaha Baru (INWUB). INWUBFE UNTAN tersebut mulai beraktivitas pada Bulan April 2008. Keberadaan INWUB FE UNTAN ini bertujuan untuk membantu mahasiswa dan alumni FE UNTAN yang berminat menjadi wirausahawan dalam bentuk: (1) sarana fisik atau fasilitas kantor yang dapat dipakai secara bersama, (2) kesempatan akses dan pembentukan jaringan kerja dan informasi dan pendanaan, (3) pelayanan konsultasi yang meliputi aspek teknologi, manajemen dan pemasaran, (4) pembentukan jaringan kerja antar pengusaha pemula dan (5) pengembangan produk penelitian untuk dapat diproduksi secara komersial. Mahasiswa yang dilibatkan sebagai peserta INWUB adalah para mahasiswa penerima beasiswa atau mahasiswa yang telah mengambil mata kuliah kewirausahaan atau mahasiswa yang telah selesai mengikuti kegiatan KKM yang memiliki minat untuk berwirausaha. Selain mahasiswa, peserta INWUB FE UNTAN ini juga berasal dari alumni FE UNTAN.

Selain mendirikan INWUB, Bagian Kemahasiswaan dan Alumni FE UNTAN pada masa itu juga mencoba untuk mendirikan mini banking yang berfungsi untuk memberikan layanan pendanaan baik bagi mahasiswa dan alumni FE UNTAN yang telah meriuntis usaha maupun usaha milik para SMA/SMK. Gambaran pengembangan kewirausahaan di FE UNTAN melalui pendirian INWUB dan mini banking dapat dilihat pada Gambar 1.

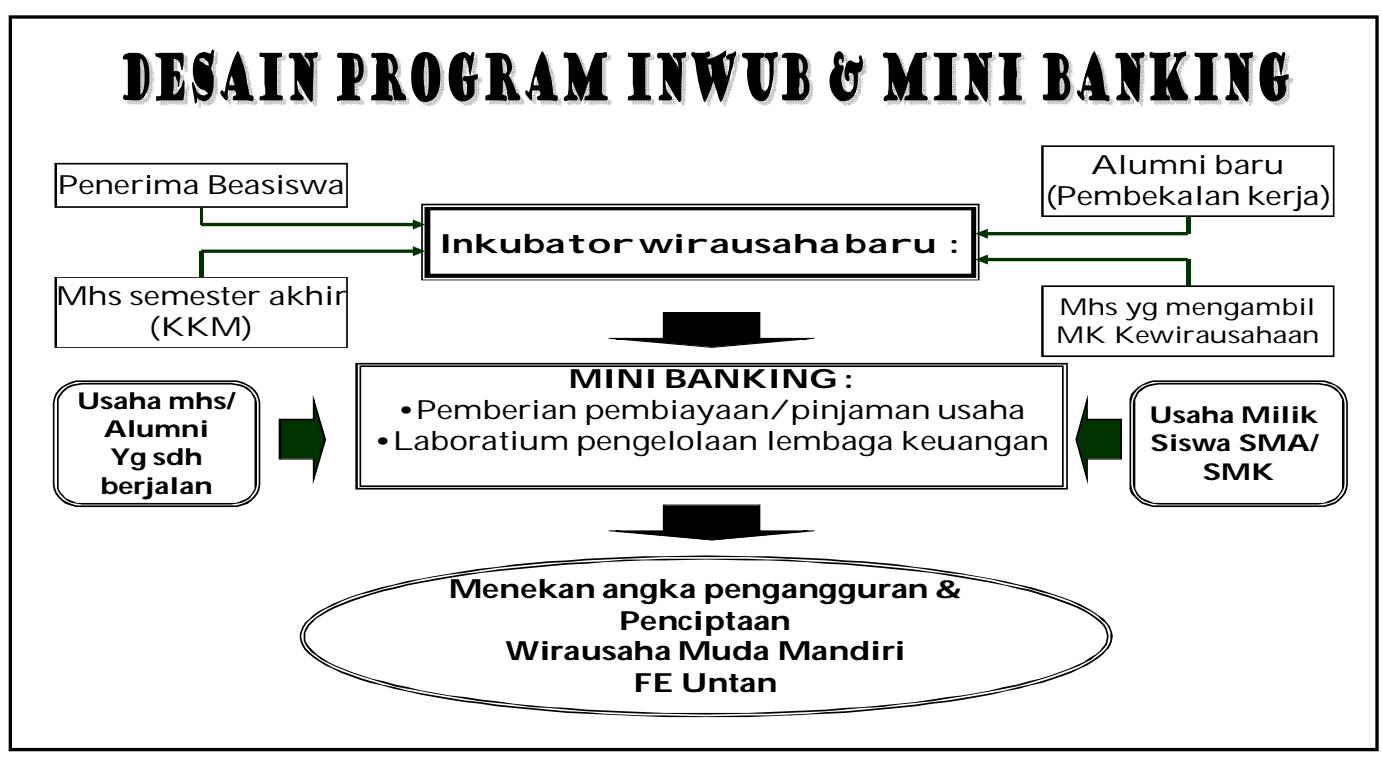

Sumber : Laporan Bidang Kemahasiswaan dan Alumni FE Untan (2014)

Gambar 1. Program Pengembangan Kewirausahaan di Kalangan Mahasiswa FE Untan Melalui INWUB \& Mini Banking 
Pada tahap selanjutnya, INWUB FE UNTAN yang saat ini berubah namanya menjadi Pusat Inkubator Bisnis FE UNTAN mengembangkan 2 macam program, yaitu program bagi tenant yang membutuhkan sarana fisik ruang usaha (disebut inwall tenant) dan yang tidak membutuhkan sarana fisik (disebut outwall tenant). Sejak Bulan Juli Tahun 2009, Pusat Inkubator Bisnis FE UNTAN juga memberikan pembinaan dan pendampingan bagi mahasiswa UNTAN yang menjadi peserta PMW UNTAN.

Dalam pengembangan selanjutnya, Pusat Inkubator Bisnis FE UNTAN sejak Tahun 2009 selalu berupaya untuk melakukan langkah-langkah sinergi dengan berbagai program yang ada di dalam kampus seperti PKM-K dan PMW maupun program kewairausahaan yang ada di luar kampus seperti Program Wirausaha Mandiri (PWM) yang merupakan program corporate social rensponsbility (CSR) Bank Mandiri, Kemeneterian Pemuda dan Olahraga R.I serta kementerian Koperasi dan UKM R.I.Upaya sinergisitas ini dilakukan dengan memprioritaskan penerima dana dari PMW Untan adalah mahasiswa-mahasiswa yang telah memulai usaha dan atau yang telah mencoba memulai usaha dengan mengimplementasikan PKM-K atau PKM lainnya yang telah diperoleh. Upaya sinergisitas juga dilakukan dengan selalu mengikutsertakan berbagai usaha yang telah didanai oleh PMW untuk mengikuti berbagai kompetisi yang dilaksanakan berbagai pihak di luar kampus, diantaranya Kompetisi Wirausaha Mandiri. Dengan pola seperti ini diharapkan para mahasiswa dan alumni baru UNTAN yang telah memulai menjadi seorang wirausaha memiliki akses pendanaan mulai dari dana yang bersifat hibah, pinjaman lunak sampai kepada pinjaman komersil/bagi Usaha Kecil dan Menengah serta akses pasar.

Selain itu, Tim Pelaksana juga selalu mengikutsertakan para mahasiswa UNTAN tersebut dalam berbagai kompetisi yang diadakan oleh Kementerian Pemuda dan Olahraga R.I diantara kompetisi business plan dan kompetisi inovasi bisnis.Berbagai program kewirausahaan tersebut baik yang berada di dalam maupun diluar kampus kemudian oleh penulis pada Tahun 2011 dicoba untuk disinergikan, dimana model sinergisitas program kewirausahaan di UNTAN dapat dilihat pada Gambar 2.

Berdasarkan Gambar 2, maka pengembangan kewirausahaan dengan mensinergikan berbagai program kewirausahaan baik di dalam maupun di luar kampus dapat dijelaskan sebagai berikut :

1. Unit Kegiatan Mahasiswa Kewirausahaan (UKM KWU) : Pada tahap awal, mahasiswa masuk dalam wadah ini. Fungsi utama UKM KWU ini adalah untuk mempersiapkan mahasiswa-mahasiswa menghasilkan proposal PKM khususnya PKM-K yang didanai oleh DP2M DIKTI. Proposal PKM-K yang tidak lolos, namun dianggap layak bisa diajukan untuk mendapatkan pendanaan dari dana CSR Bank Mandiri yang diperuntukkan bagi mahasiswa yang telah mengambil mata kuliah kewirausahaan maupun yang berasal dari CSR pihak lainnya serta berbagai program kewirausahaan yang ada di pemerintah. 


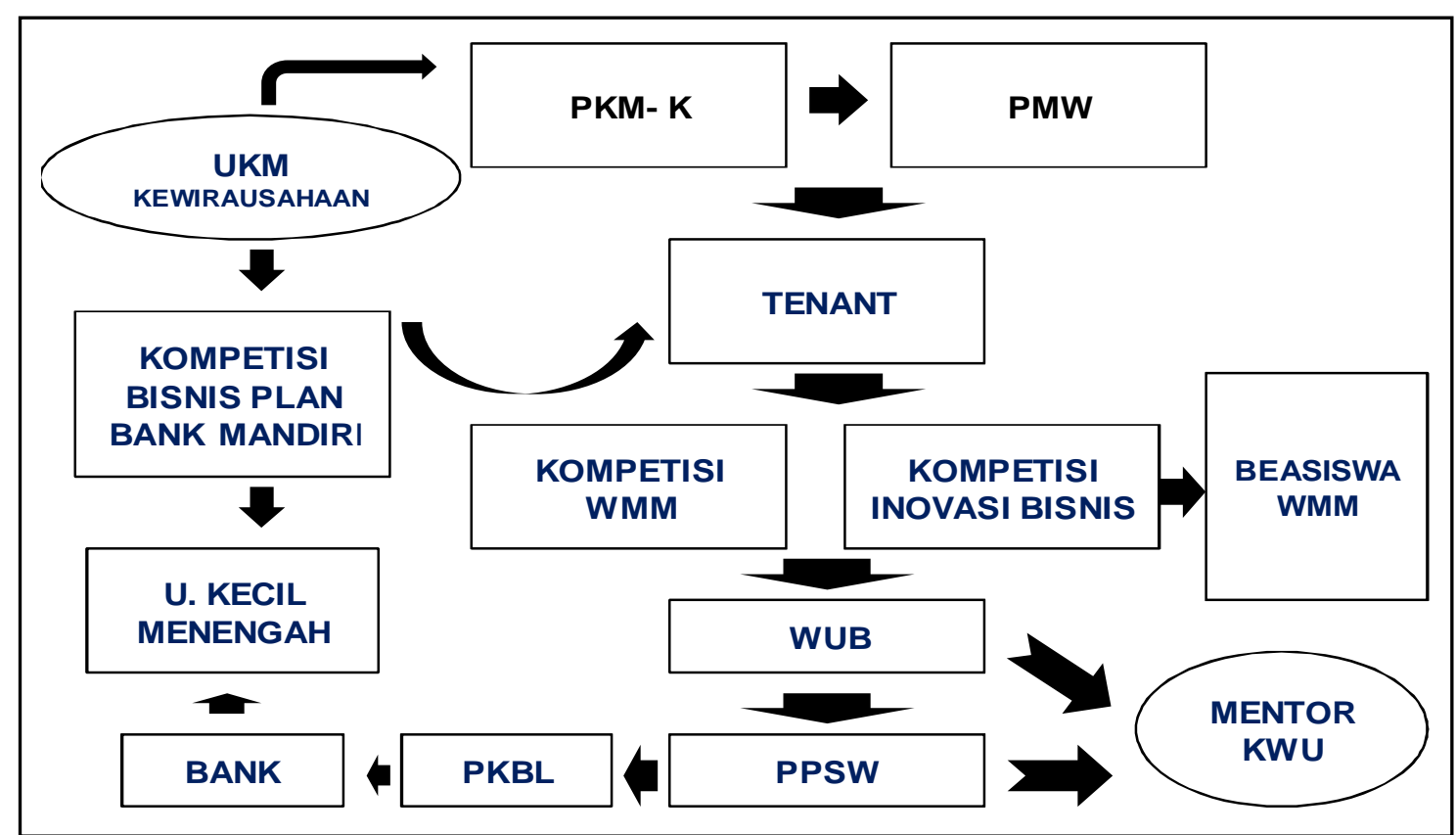

Sumber : Buku Pendidikan Karakter Kewirausahaan, 2011

Gambar 2 :Model Sinergisitas Program Kewirausahaan di UNTAN

2. PKM-K. Mahasiswa yang lolos PKM-K selanjutnya dibina untuk menjadi tenant. Para tenant ini dibina oleh Pusat Inkubator BisnisFE UNTAN. Jika dalam perkembangannya membutuhkan tambahan dana, maka para tenant ini akan diusulkan untuk mendapatkan pendanaan dari Program Mahasiswa Wirausaha (PMW) UNTAN atau juga dari berbagai pihak yang mensyaratakan memberikan bantuan/pembiayaan pada usaha yang sudah berjalan.

3. Mahasiswa yang telah mendapatkan pendanaan dari kompetisi Business Plan Bank Mandiriselanjutnya akan dibina untuk menjadi tenant. Jika dalam perkembangannya membutuhkan tambahan dana akan diusulkan untuk mendapatkan pendanaan dari Bank Mandiri.

4. Mahasiswa yang mendapatkan pendanaan dari Kompetisi Business Plan Bank Mandiri dan PMW Untan diwajibkan untuk mengikuti Kompetisi Wirausaha Mandiri dan Kompetisi Inovasi Bisnis Kemenpora RI.

5. Bagi mereka yang terpilih untuk mengikuti 2 kompetisi tersebut akan diusulkan untuk mendapatkan dana Beasiswa Wirausaha Mandiri yang merupakan program CSR Bank Mandiri.

6. Tenant yang usahanya terus berkembang dan membutuhkan tambahan dana dapat diusulkan untuk mendapatkan pinjaman dana dari Program Kemitraan dan Bina Lingkungan (PKBL) BUMN dan selanjutnya dapat berasal dari dana dari perbankan dalam program Kredit Usaha Rakyat (KUR). 
7. Tenant yang usahanya terus berkembang dan berstatus sarjana dapat diikutkan dalam Program Penumbuhan dan Pengembangan Sarjana Wirausaha (PPSW) yang merupakan program dari Kementerian Negara Koperasi dan UKM RI.

8. Tenant yang usahanya terus berkembang dan akhirnya menjadi Wirausaha Baru dapat diusulkan untuk menjadi Mentor Kewirausahaan dalam Program Pengembangan Kewirausahaan Bagi Pemuda se-Kota Pontianak serta kabupaten/kota lainnya.

Tabel 1. Prestasi Yang Diperoleh Tenant Binaan Pusat Inkubator Bisnis FE UNTAN Tahun 2008 - 2014

\begin{tabular}{|c|c|c|c|}
\hline No & $\begin{array}{c}\text { Nama } \\
\text { Mahasiswa/Alumni }\end{array}$ & Fakultas & Nama Kompetisi \\
\hline \multirow[t]{2}{*}{1} & Fakhrurazi,SE & Ekonomi & $\begin{array}{l}\text { - Juara } 1 \text { Kompetisi Wirausaha Mandiri Kategori Alumni } \\
\text { Regional Kalimantan Tahun } 2008\end{array}$ \\
\hline & & & $\begin{array}{l}\text {-Finalis Kompetisi Wirausaha Mandiri Tingkat Nasional } \\
\text { Tahun } 2008 \text { Kategori Alumni }\end{array}$ \\
\hline 2 & Jefri & Kehutanan & $\begin{array}{l}\text { - Juara } 1 \text { Kompetisi Wirausaha Mandiri Tingkat Regional } \\
\text { Kalimantan Tahun } 2009 \text { Kategori Industri Kreatif }\end{array}$ \\
\hline 3 & Paridi & Pertanian & $\begin{array}{l}\text { - Juara } 2 \text { Kompetisi Wirausaha Mandiri Tingkat Regional } \\
\text { Kalimantan Tahun } 2009 \text { Kategori Industri Kreatif }\end{array}$ \\
\hline 4 & Elita & MIPA & $\begin{array}{l}\text { - Juara } 1 \text { Kompetisi Business Plan HIPMI Kalbar Tahun } \\
2009\end{array}$ \\
\hline 5 & Melati Fajriawati,Spd & KIP & $\begin{array}{l}\text {-Juara } 1 \text { Kompetisi Wirausaha Mandiri Tingkat Regional } \\
\text { Kalimantan Tahun } 2010 \text { Kategori Industri }\end{array}$ \\
\hline 6 & $\begin{array}{l}\text { Benny Tan } \\
\text { Haery,S.Hut }\end{array}$ & Kehutanan & $\begin{array}{l}\text {-Juara } 1 \text { Kompetisi Wirausaha Mandiri Tingkat Regional } \\
\text { Kalimantan Tahun } 2010 \text { Kategori Industri Kreatif }\end{array}$ \\
\hline 7 & Elita & MIPA & $\begin{array}{l}\text {-Juara } 2 \text { Kompetisi Business Plan Tingkat Nasional Yang } \\
\text { Diadakan Kementerian Pemuda dan Olahraga R.I Tahun } \\
2010\end{array}$ \\
\hline 8 & Elita & MIPA & $\begin{array}{l}\text { - Juara } 1 \text { Kompetisi Inovasi Bisnis Pemuda Tahun } 2011 \\
\text { yang diadakan oleh Kementerian Pemuda dan Olahraga } \\
\text { RI }\end{array}$ \\
\hline 9 & Leopratama Limas & Ekonomi & $\begin{array}{l}\text {-Juara } 1 \text { Kompetisi Wirausaha Mandiri Tingkat Regional } \\
\text { Kalimantan Tahun } 2011 \text { ketegori kreatif }\end{array}$ \\
\hline 10 & Widya Arini & Ekonomi & $\begin{array}{l}\text {-Juara } 1 \text { Kompetisi Wirausaha Mandiri Tingkat Regional } \\
\text { Kalimantan Tahun } 2011 \text { ketegori Jasa }\end{array}$ \\
\hline 11 & Elita & MIPA & $\begin{array}{l}\text {-Juara } 1 \text { Kompetisi Wirausaha Mandiri Tingkat Regional } \\
\text { Kalimantan Tahun } 2011 \text { ketegori industri }\end{array}$ \\
\hline 12 & Setiadi Wijaya & Ekonomi & $\begin{array}{l}\text {-Juara } 1 \text { Kompetisi Wirausaha Mandiri Tingkat Regional } \\
\text { Kalimantan Tahun } 2012 \text { ketegori kreatif }\end{array}$ \\
\hline 13 & $\begin{array}{l}\text { Puan Sonia } \\
\text { Miftahuljannah }\end{array}$ & Ekonomi & $\begin{array}{l}\text { - Juara } 1 \text { Kompetisi Wirausaha Mandiri Tingkat Regional } \\
\text { Kalimantan Tahun } 2012 \text { ketegori Jasa }\end{array}$ \\
\hline 14 & M. Kemal Reza & Ekonomi & $\begin{array}{l}\text {-Juara } 1 \text { Kompetisi Wirausaha Mandiri Tingkat Regional } \\
\text { Kalimantan Tahun } 2014 \text { ketegori Jasa }\end{array}$ \\
\hline 15 & Izhar & Ekonomi & $\begin{array}{l}\text { - Juara } 1 \text { java Business Competition di Universitas Telkom, } \\
\text { Bandung Tahun } 2014\end{array}$ \\
\hline
\end{tabular}

Sumber : Laporan Bidang Kemahasiswaan dan ALUMNI FE UNTAN, 2015

Dengan mensinergikan berbagai program kewirausahaan baik di dalam mamupun diluar kampus telah banyak prestasi yang diraih oleh mahasiswa UNTAN dalam program 
kwirausahaan. Berbagai prestasi yang diraih oleh mahasiswa UNTAN yang merupakan binaan Pusat Inkubator Bisnis FE UNTAN dapat dilihat pada Tabel 1.

Dengan berbagai pencapaian ini, menunjukkan bahwa Pusat Inkubator Bisnis FE UNTAN memiliki potensi dalam mengembangkan kemampuan kewirausahaan para mahasiswa Universitas Tanjungpura serta dalam menghasilkan wirausaha baru. Kedepannya, Pusat Inkubator Bisnis FE UNTAN akan terus dikembangkan dalam pengembangan sosiopreneur dan technopreneur.

\subsection{Desain Pengembangan Aktivitas Kemahasiswaan Dengan Pendekatan Psychological Capital}

Hasil evaluasi terhadap usaha yang dijalankan oleh mahasiswa Fakultas Ekonomi UNTAN yang telah didanai dari PMW UNTAN dari Tahun 2009 s.d. 2013 ada 2 (dua) isu utama yang dianggap perlu diperhatikan, dimana 2 isu ini menjadi dasar dalam penyusunan desain pengembangan aktivitas kemahasiswaan dalam meningkatkan minat dan kemampuan berwirausaha mahasiswa fakultas Ekonomi UNTAN.

Isu yang pertama adalah sistem rekrutment peserta penerima dana PMW UNTAN. Berdasarkan hasil wawancara salah satu penyebab tidak efektifnya PMW dalam mencetak seorang wirausahawan adalah karena sistem perekrutan peserta PMW UNTAN yang kurang tepat. Seharusnya, perekrutan lebih diarahkan kepada para mahasiswa yang telah merintis usaha dari sejak mereka menjadi mahasiswa baru, bukannya kepada para mahasiswa yang baru mau mencoba. Sehingga dalam konsep perbaikannya, mahasiswa yang diusulkan untuk menerima dana PMW UNTAN merupakan mahasiswa yang telah lolos seleksi menjadi tenant yang akan dibina oleh Pusat Inkubator Bisnis FE UNTAN.

Selanjutnya, isu yang kedua adalah pola pembinaan kewirausahaan kepada peserta. Selama ini, pola pembinaan kepada peserta lebih terfokus kepada hal-hal yang bersifat teknis, seperti penyusunan businesss plan, pembukuan, dan lain sebagainya. Padahal, pada saat peserta ingin mengembangkan usahanya, pembinaan yang paling diperlukan adalah berkaiatan dengan pembinaan mental psikologis peserta.

Selanjutnya, pada Gambar 3 dapat dilihat desain yang diusulkan dalam pengembangan aktivitas kemahasiswaan dengan pendekatan psychological capital dalam meningkatkan minat dan kemampuan berwirausaha mahasiswa Fakultas Ekonomi UNTAN.

\section{KESIMPULAN}

Sebenarnya program dalam rangka mencetak para wirausaha di Indonesia cukup banyak. Diantara program tersebut ada dalam bentuk pemberian pendanaan yang bersifat pinjaman atau yang bersifat hibah maupun dalam bentuk pembinaan pelatihan dan 
pendampingan. Namun, mendorong orang-orang muda khususnya para mahasiswa untuk menjadi seorang wirausaha bukanlah hal yangmudah, jika mudah tentunya jumlah wirausaha di negeri ini akan banyak jumlahnya.

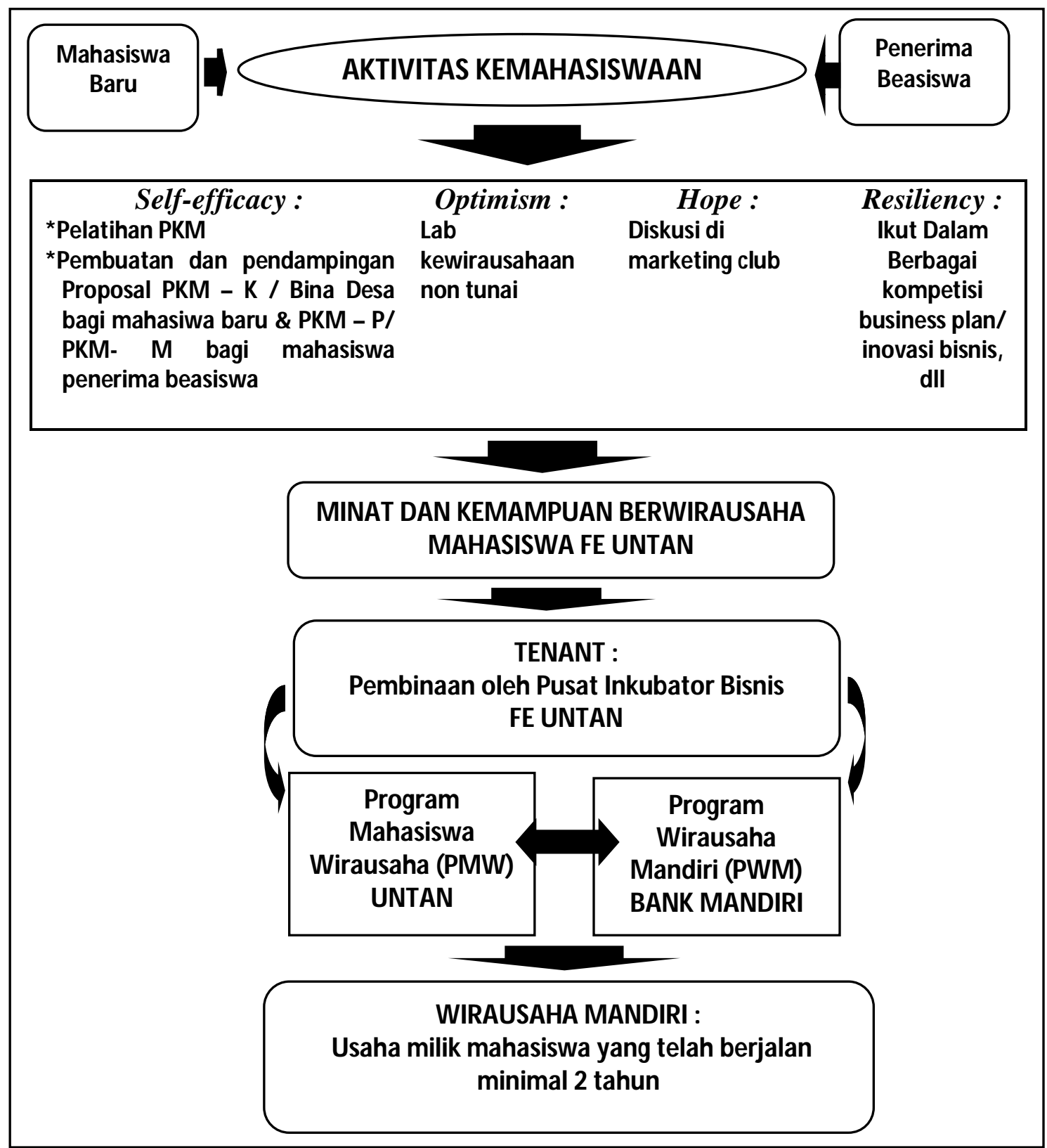

Gambar 3. Desain Pengembangan Aktivitas Kemahasiswaan Dengan Pendekatan Psychological Capital Dalam Rangka Meningkatkan Minat dan Kemampuan Berwirausaha Mahasiswa FE UNTAN

Hal tersulit dalam mencetak seorang wirausaha adalah dalam merubah mental yang terbentuk karena pola pikir yang merupakan sinergisitas dari berbagai interaksi kita sehari-hari (keluarga, dunia pendidikan, lingkungan dll). Mental yang dimaksud disini 
adalah mental ingin mendapatkan sesuatu secara instant. Mental yang tidak percaya diri dan mental yang cepat menyerah. Untuk itu sebagai upaya memecahkan masalah mental tersebut perlu sinergisitas dari berbagai program penumbuhan kewirausahaan yang sudah ada. Sinergisitas dapat dilakukan tanpa mempengaruhi independensi pelaksanaan program dari masing-masing pihak pelaksana penumbuhan kewirausahaan tersebut. Dengan sinergisitas ini diharapkan dapat melahirkan para wirausaha muda yang mandiri dan memiliki mental yang tangguh.

Desain pengembangan aktivitas kemahasiswaan dengan pendekatan psychological capital ini merupakan sebuah hasil evaluasi dari pelaksanaan program kewirausahaan yang telah dilaksanakan di Fakultas Ekonomi UNTAN. Dimana desain yang ditawarkan ini lebih mengedepankan pengoptimalan faktor potensi psikologis para mahasiswa, sehingga dengan desain pengembangan aktivitas kemahasiswaan ini diharapkan dapat mencetak sebanyak mungkin para aktivis penyebar virus kewirausahaan di kalangan mahasiswa.

\section{DAFTAR PUSTAKA}

Bandura, A. (1997). Self-efficiecy: The exercise of control. New York: Freeman.

Bagian Kemahasiswaan UNTAN. (2014). Laporan Tahunan Bidang Kemahasiswaan UNTAN.

Direktorat Jenderal Pendidikan Tinggi. (2009). Pedoman Program Mahasiswa Wirausaha.

Hendri, I. M. (2011). Aktivis Penyebar Virus Kewirausahaan. Tribune Pontianak.

Hendri, I. M. (2012). Sinergisitas Program Kewirausahaan Dalam Mengembangkan Budaya Kewirausahaan di Universitas Tanjungpura. Prosiding Seminar Nasional dan Call For Papers Tantangan Pendidikan Kewirausahaan di Perguruan Tinggi Pada Era Global, Universitas Jember, 22 September 2012.

Indarti, N. \& Rostianti, T. (2008). Intensi Kewirausahaan Mahasiswa: Studi Perbandingan Antara Indonesia, Jepang dan Norwegia Jurusan Management, Fakultas Ekonomi, Universitas Gadjah Mada. Jurnal Ekonomi dan Bisnis Indonesia 23 (4).

Luthans, F., Youssef, C.M., \& Avolio, B.J. (2007). Psychological capital: Developing the human competitive edgte. New York : Oxford University Press.

Masten, A. S., \& Reed, M. J. (2002). Resiliency in development. In C.R. Snyder \& S. Lopez (eds.), Handbook of positive psychology. Oxford University Press.

Osigweh, C. A. B. (1989). Concept fallibility in organizational science. The Management Review, 14 (4), 579-594. 
Pengelola Program Mahasiswa Wirausaha UNTAN. (2014). Laporan Pelaksanaan Program Mahasiswa Wirausaha (PMW) UNTAN Tahun 2014.

Suratman, dkk. (2011). Pendidikan Karakter Kewirausahaan., Pontianak: UNTAN Publishing

Sastri, H. (2010). Pengaruh Program mahasiswa Wirausaha Terhadap Minat Berwirausaha Fakultas Keguruan dan Ilmu Pendidikan Tahun 2009. Skripsi. Program Pendidikan Ekonomi Jurusan Ilmu Pengetahuan Sosial FKIP UNTAN.

Suryana. (2004). Modul Kewirausahaan SMK. Jakarta: Direktorat Pendidikan Menengah Kejuruan Departemen Pendidikan Nasional.

Stajkovic, A. D., \& Luthans, F. (2001). The differential effects of incentive motivators on work performance. Academy of Management Journal, 4, 580.

Schulman, P. (1999). Applying Learned Optimism to Increase Sales Productivity. Journal of Personal Selling and Sales Management 19 (1), 31-37.

Seligman, M. (1998). Learned Optimism. New York: Pocket Books.

Snyder, C. R. (1994). Hope and Optimism. Encyclopedia of Human Behavior (vol.2, 535-542). San Diego: Academic Press.

Snyder, C. R., Irving, L, \& Anderson, J. (1991). Hope and Health : Measuring The Will and The Ways. In C.R. Snyder \& D. R. Forsyth (Eds). Handbook of Social and Clinical Psychology (285-305). Elmsford, NY: Pergamon.

Woling, S. J., \& Wolin, S. (1994). The Resilient Self: How Survivors of Trouble Families Rise Above Adversity. New York: Villard Books.

Majalah Bank Mandiri. (2011). Program Wirausaha Mandiri. 


\section{Lampiran 1. Daftar Usulan Usulan dan Penerima PKM Mahasiswa Berdasarkan Jenis PKM dan Fakultas}

Tahun 2007 - 2014

\begin{tabular}{|c|c|c|c|c|c|c|c|c|c|c|c|c|}
\hline \multirow{3}{*}{ FAKULTAS } & & \multicolumn{2}{|c|}{$\begin{array}{c}\text { TAHUN } \\
2008 \\
\end{array}$} & \multicolumn{2}{|c|}{$\begin{array}{c}\text { TAHUN } \\
2009\end{array}$} & \multicolumn{2}{|c|}{$\begin{array}{c}\text { TAHUN } \\
2010\end{array}$} & $\begin{array}{c}\text { TAHUN } \\
2011\end{array}$ & $\begin{array}{c}\text { TAHUN } \\
2012\end{array}$ & $\begin{array}{c}\text { TAHUN } \\
2013\end{array}$ & \multicolumn{2}{|c|}{$\begin{array}{c}\text { TAHUN } \\
2014\end{array}$} \\
\hline & & & & USL & & & & USL DTR & USL DTR & USL DTR & & DTR \\
\hline & PKM & 2007 & 2008 & 2008 & 2009 & 2009 & 20102 & 20102011 & 20112012 & 20122013 & 2013 & 2014 \\
\hline \multirow{4}{*}{ HUKUM } & PKM-P & & & 2 & 2 & 2 & 1 & & & & & 1 \\
\hline & PKM-K & & & 1 & 1 & 1 & & & & & & \\
\hline & PKM-M & & & 1 & 1 & 1 & & & & & & \\
\hline & PKM-T & & & & & & & & & & & \\
\hline Sub total & & 0 & 0 & 4 & 4 & 4 & 1 & & & & & 1 \\
\hline \multirow{4}{*}{ EKONOMI } & PKM-P & & & 5 & 5 & 5 & 3 & 4 & 14 & & 17 & 5 \\
\hline & PKM-K & & & 10 & 10 & 10 & 2 & 5 & 9 & & 65 & 12 \\
\hline & PKM-M & & & 3 & 3 & 3 & & 2 & & & 5 & 2 \\
\hline & PKM-T & & & & & & & & & & & \\
\hline Sub total & & 0 & 0 & 18 & 18 & 18 & 5 & 11 & 23 & & 87 & 19 \\
\hline \multirow{4}{*}{ PERTANIAN } & PKM-P & & 10 & 2 & 2 & 2 & & & 1 & & & 2 \\
\hline & PKM-K & & 1 & 9 & 9 & 9 & 1 & & 2 & & & 7 \\
\hline & PKM-M & & 4 & 11 & 11 & 11 & 2 & & & & & 2 \\
\hline & PKM-T & & & & & & & & & & & \\
\hline Sub total & & 0 & 15 & 22 & 22 & 22 & 3 & & 3 & & & 11 \\
\hline \multirow{5}{*}{ TEKNIK } & PKM-P & & 1 & 4 & 4 & 4 & 1 & & 7 & & & \\
\hline & PKM-K & & & 6 & 6 & 6 & & & 4 & & & 5 \\
\hline & PKM-M & & & 2 & 2 & 2 & & & 4 & & & 1 \\
\hline & PKM-T & & & 3 & 3 & 3 & 1 & & 1 & & & 3 \\
\hline & PKM-KC & & & & & & & & 5 & & & 2 \\
\hline Sub total & & 0 & 1 & 15 & 15 & 15 & 2 & & 22 & & & 11 \\
\hline \multirow{4}{*}{ FISIP } & PKM-P & & & 1 & 1 & 1 & & & & & & 1 \\
\hline & PKM-K & & & 1 & 1 & 1 & & & & & & 1 \\
\hline & PKM-M & & & 1 & 1 & 1 & & & & & & \\
\hline & PKM-T & & & & & & & & & & & \\
\hline Sub total & & 0 & 0 & 3 & 3 & 3 & 0 & & & & & 2 \\
\hline \multirow{4}{*}{ FKIP } & PKM-P & & & 14 & 14 & 14 & 6 & & 8 & & & 3 \\
\hline & PKM-K & & & 1 & 1 & 1 & & & 1 & & & 2 \\
\hline & PKM-M & & & 14 & 14 & 14 & & & 1 & & & 2 \\
\hline & PKM-T & & & & & & & & & & & \\
\hline Sub total & & 0 & 0 & 29 & 29 & 29 & 6 & & 10 & & & 7 \\
\hline \multirow{4}{*}{ KEHUTANAN } & PKM-P & & 1 & 2 & 2 & 2 & 2 & & & & & 1 \\
\hline & PKM-K & & & & & & & & 1 & & & 1 \\
\hline & PKM-M & & & 1 & 1 & 1 & & & & & & \\
\hline & PKM-T & & & & & & & & & & & \\
\hline Sub total & & 0 & 1 & 3 & 3 & 3 & 2 & & 1 & & & 2 \\
\hline \multirow{5}{*}{ MIPA/KIK } & PKM-P & & 8 & 25 & 25 & 25 & 9 & & 15 & & & 16 \\
\hline & PKM-K & & & 2 & 2 & 2 & 1 & & 1 & & & 5 \\
\hline & PKM-M & & & 2 & 2 & 2 & & & 1 & & & 2 \\
\hline & PKM-T & & & 1 & 1 & 1 & & & & & & 1 \\
\hline & PKM-KC & & & & & & & & & & & 1 \\
\hline Sub total & & 0 & 8 & 30 & 30 & 30 & 10 & & 17 & & & 25 \\
\hline
\end{tabular}




\begin{tabular}{|c|c|c|c|c|c|c|c|c|}
\hline \multirow{2}{*}{ FAKULTAS } & & $\begin{array}{c}\text { TAHUN } \\
2008 \\
\end{array}$ & $\begin{array}{l}\text { TAHUN } \\
2009 \\
\end{array}$ & $\begin{array}{c}\text { TAHUN } \\
2010 \\
\end{array}$ & $\begin{array}{c}\text { TAHUN } \\
2011 \\
\end{array}$ & $\begin{array}{c}\text { TAHUN } \\
2012 \\
\end{array}$ & $\begin{array}{l}\text { TAHUN } \\
2013 \\
\end{array}$ & $\begin{array}{c}\text { TAHUN } \\
2014 \\
\end{array}$ \\
\hline & PKM & $\begin{array}{l}\text { USL DTR } \\
20072008 \\
\end{array}$ & $\begin{array}{l}\text { USL DTR } \\
20082009 \\
\end{array}$ & $\begin{array}{l}\text { USL DTR } \\
20092010\end{array}$ & $\begin{array}{l}\text { USL DTR } \\
2010201\end{array}$ & $\begin{array}{l}\text { USL DTR } \\
20112012\end{array}$ & $\begin{array}{l}\text { USL DTR } \\
20122013 \\
\end{array}$ & $\begin{array}{l}\text { USL DTR } \\
20132014\end{array}$ \\
\hline Lanjutan & $\begin{array}{l}\text { PKM-P } \\
\text { PKM-K } \\
\text { PKM-M } \\
\text { PKM-T }\end{array}$ & & & & & 2 & & $\begin{array}{c}16 \\
5 \\
3\end{array}$ \\
\hline $\begin{array}{l}\text { Sub Total } \\
\text { Grand to }\end{array}$ & & 25 & $\begin{array}{ll}71 & 124 \\
\end{array}$ & $124 \quad 29$ & 32 & $\begin{array}{c}2 \\
80 \\
\end{array}$ & & $\begin{array}{r}\frac{24}{102} \\
\end{array}$ \\
\hline
\end{tabular}

Sumber : Bagian Kemahasiswaan UNTAN (2014) 